\title{
Temporal variability and production of Temora turbinata (Copepoda: Calanoida) in the Cananéia Lagoon estuarine system, São Paulo, Brazil*
}

\author{
KOICHI ARA \\ Instituto Oceanográfico, Universidade de São Paulo, São Paulo, SP 05508-900, Brazil. \\ Present address: Department of Marine Science and Resources, College of Bioresource Sciences, Nihon University, \\ Fujisawa, Kanagawa 252-8510, Japan. E-mail: arakoich@brs.nihon-u.ac.jp
}

\begin{abstract}
SUMMARY: Diel and seasonal variations in abundance, population structure, biomass and production rate of the planktonic calanoid copepod Temora turbinata were studied in the Cananéia Lagoon estuarine system, São Paulo, Brazil. Zooplankton sample collections were carried out at 4-h intervals over multiple 24-h periods, from February 1995 to January 1996. Temora turbinata was present in the plankton all year round (temperature, $18.6-29.6^{\circ} \mathrm{C}$; salinity, 8-33 psu; chlorophyll $a$ concentration, 1.32-15.33 $\mu \mathrm{g} \mathrm{l}^{-1}$ ). Temora turbinata showed considerable diel variations in abundance. Abundance of T. turbinata was higher from June to October when temperature was lower than ca. $24^{\circ} \mathrm{C}$ and salinity was higher than ca. 20 psu. The biomass varied from $0.0005 \pm 0.0014$ to $3.715 \pm 2.360 \mathrm{mgC} \mathrm{m}^{-3}$ (daily mean $\pm \mathrm{SD}$ ). The daily production rates estimated by the Hirtst-Sheader models varied from $0.0002 \pm 0.0006$ to $1.115 \pm 0.261 \mathrm{mgC} \mathrm{m}^{-3} \mathrm{~d}^{-1}$ (mean $\pm \mathrm{SD}$ ). The P/B ratios varied from 0.17 to $0.45 \mathrm{~d}^{-1}$. These results showed that $T$. turbinata constituted 8.3 and $7.8 \%$ of the annual copepod community biomass and production rate respectively.
\end{abstract}

Key words: Temora turbinata, temporal variation, population structure, production, Cananéia Lagoon estuarine system, Brazil.

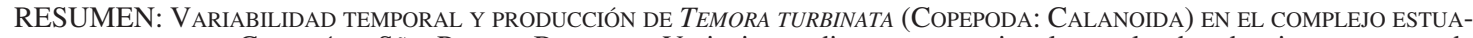
Rino-lagunar de Cananéia, São Paulo, Brasil. - Variaciones diurnas y estacionales en la abundancia, estructura de población, biomasa y tasa de producción del copépodo calanoide planctónico Temora turbinata fueron estudiadas en el sistema estuarino Cananéia Lagoon, São Paulo, Brasil. Muestras de zooplancton fueron obtenidas a intervalos de 4 horas a lo largo de múltiples períodos de $24 \mathrm{~h}$ desde febrero 1995 hasta enero 1996. T. turbinata estuvo presente en el plancton durante todo el año (temperatura, $18.6-29.6^{\circ} \mathrm{C}$; salinidad, 8-33 psu; concentración de clorofila $a, 1.32-15.33 \mu \mathrm{g} \mathrm{l^{-1 }}$ ). T. turbinata mostró considerables variaciones diurnas en su abundancia. Ésta fue mayor de junio a octubre cuando la temperatura era inferior a alrededor de $24^{\circ} \mathrm{C}$ y la salinidad era superior a alrededor de 20 psu. La biomasa varió entre $0.0005 \pm 0.0014$ y 3.715 $\pm 2.360 \mathrm{mgC} \mathrm{m}^{-3}$ (media diaria $\pm \mathrm{SD}$ ). Las tasas de producción diaria estimadas por los modelos de Hirtst-Sheader variaron entre $0.0002 \pm 0.0006$ y $1.115 \pm 0.261 \mathrm{mgC} \mathrm{m}^{-3} \mathrm{~d}^{-1}$ (media $\pm \mathrm{SD}$ ). Los cocientes P/B variaron entre 0.17 y $0.45 \mathrm{~d}^{-1}$. Estos resultados muestran que T. turbinata constituyó, respectivamente, el $8.3 \%$ y el $7.8 \%$ de la biomasa anual de la comunidad de copépodos y de la tasa de producción.

Palabras clave: Temora turbinata, variación temporal, estructura poblacional, complejo estuarino-lagunar de Cananéia, Brasil. 


\section{INTRODUCTION}

Planktonic copepods of the family Temoridae are widely distributed in tropical, subtropical, temperate and subboreal waters, and are one of the conspicuous members of the surface and near-surface mesozooplankton communities in estuarine, neritic and oceanic waters.

Along the western coast of the Atlantic, 3 species of the genus Temora (T. longicornis, T. stylifera and T. turbinata) have been recorded (Bradford-Grieve et al., 1999). Among these, Temora turbinata (Dana, 1849 ) is widely distributed in tropical, subtropical and temperate waters of the Atlantic, Pacific and Indian Oceans, except in the eastern Pacific (Fleminger, 1975; Haedrich and Judkins, 1979; Bradford-Grieve et al., 1999), and is often predominant in the mesozooplankton communities of tropical, coastal and oceanic environments of the Gulf of Mexico and the Caribbean Sea (Suárez-Morales and Gasca, 1997, 2000; López-Salgado and SuárezMorales, 1998).

In recent years, T. turbinata has been found to appear in various estuarine and neritic waters of Brazil (e.g. Araújo and Montú, 1993; Muxagata and Gloeden, 1995; De La Rocha, 1998; Ara, 1998). The immigration of estuarine zooplankters (e.g. copepods) can be caused by ships, which carry millions of cubic meters of ballast water, transporting entire holo- and meroplankton assemblages (e.g. Orsi et al., 1983; Fleminger and Kramer, 1988; Cordell and Morrison, 1996). The introduction of exotic species that invade their new environments usually results in changes in native assemblages. In the Cananéia Lagoon estuarine system, a mangrove-surrounded estuary situated near the southern border of São Paulo State, Brazil, T. stylifera, which was formerly one of the principal copepod species (MatsumuraTundisi, 1972), was recently substituted by $T$. turbinata (Luz Amelia Vega-Pérez, Universidade de São Paulo, personal communication).

The biology and ecology of T. turbinata have been studied, e.g. developmental time and growth rate (Binet, 1977; Chisholm and Roff, 1990b; Roff et al., 1995; Hopcroft et al., 1998b; Hopcroft and Roff, 1998b), length-weight relationship (Chisholm and Roff, 1990a; Ara, 1998, 2001b), body chemical content (Hirota, 1981; Bandaranayake and Gentien 1982; Uye, 1982; Ara, 1998, 2001b), egg production rate (Hopcroft and Roff, 1998a), and biomass and production rate (Chisholm and Roff, 1990b; Hopcroft et al., 1998a). However, for T. turbinata, there have been no studies on the temporal variation in population production rate.

The objective of the present study was to obtain quantitative information on Temora turbinata, analysing the diel and seasonal variations in abundance and population structure in relation to the environmental variables, as well as to evaluate the biomass and production rate of this species in the Cananéia Lagoon estuarine system.

\section{MATERIALS AND METHODS}

A series of field investigations and sample collections were carried out at a fixed sampling station (2501'11' S, 47 $55^{\circ} 43^{\prime \prime} \mathrm{W}, 10-12 \mathrm{~m}$ in depth depending on the tidal phase) situated in Mar de Cananéia (Fig. 1), from February 1995 to January 1996. On each sampling date, sampling was carried out at intervals of 4-h during multiple 24-h periods. Zooplankton samples were taken by vertical hauls from the bottom to the surface, using a plankton net $(50 \mathrm{~cm}$ in mouth diameter, $150 \mu \mathrm{m}$ in mesh size) equipped with a flowmeter. Net samples were immediately preserved in $5-10 \%$ formalin-seawater solution.

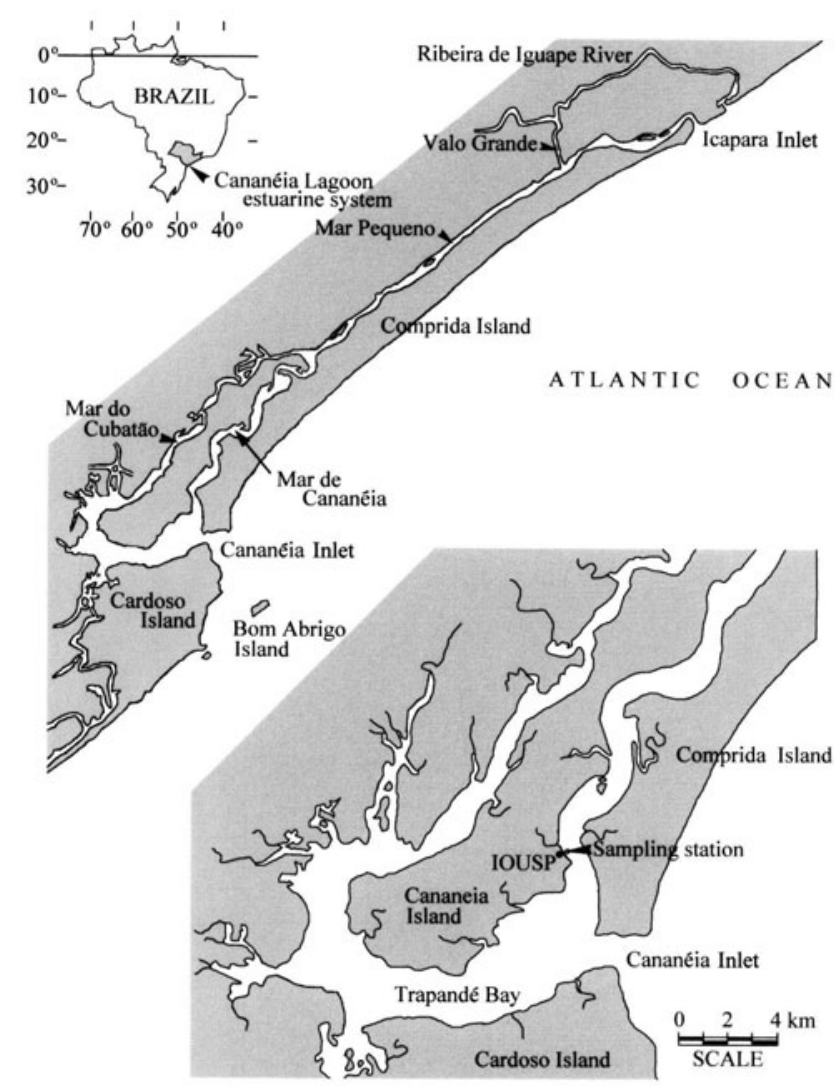

FIG. 1. - Map showing the sampling station in the Cananéia Lagoon estuarine system. 
Water samples were collected every $2 \mathrm{~m}$ from the surface to the bottom, using a 3 litre-Van Dorn bottle. Water temperature was recorded with an electronic thermometer and salinity was determined using an optical refractometer. Water aliquots (volume: 200-500 ml) collected from 0, 2, 6 and 10-m depth were filtered through a glass-fibre filter (Whatman, $\mathrm{GF} / \mathrm{F}$ ) for spectrophotometric determination of chlorophyll $a$ concentration (Lorenzen, 1967). Tidal height was cited from the tide tables given by Mesquita and Harari (1993) and Harari and Mesquita (1995).

Temora turbinata from split samples (1.25 to $40 \%$ of the original samples) was staged, sexed and counted under a microscope. Total body length of the copepodite stages $\mathrm{C} 1-5$ and C6 (adults) were measured using an eyepiece micrometer.

For statistical comparison between daytime (08:00, 12:00 and 16:00 h) and nighttime (20:00, 00:00 and 04:00 h) abundances of T. turbinata, oneway ANOVA was applied: a $p$-value of less than 0.05 was considered statistically significant (Sokal and Rohlf, 1981). Correlation between abundances of $T$. turbinata and the environmental variables (temperature, salinity, chlorophyll $a$ concentration and tidal height) was examined by Spearman rank correlation analysis. The correlation between total body length of $T$. turbinata and the environmental variables was analysed by multiple linear regression. Biomass was estimated by the multiplication of abundances and individual dry weights $(D W, \mu \mathrm{g})$ calculated from prosome body length $(P L, \mu \mathrm{m})$ using a length-weight regression equation (Ara, 1998, 2001b) given as:

$$
D W=1.471 \times 10^{-8} P L^{3.064}(r=0.972, p<0.0001) .
$$

Carbon content was assumed to be $44.6 \%$ of dry weight (Ara, 1998, 2001b).

Production rate $\left(P c, \mathrm{mgC} \mathrm{m} \mathrm{m}^{-3} \mathrm{~d}^{-1}\right)$ was estimated by the following equation:

$$
P c=\sum N \times W c \times G
$$

where $N$ is abundance (ind. $\mathrm{m}^{-3}$ ), $W c$ is individual weight $(\mu \mathrm{gC})$ and $G$ is individual weight-specific growth rate $\left(\mathrm{d}^{-1}\right)$. Here, $G$ was estimated using the model proposed by Hirst and Sheader (1997), expressed as:

$$
G=1.0583^{T} \times W c^{-0.2962} / 13.6616
$$

where $T$ is temperature $\left({ }^{\circ} \mathrm{C}\right)$.
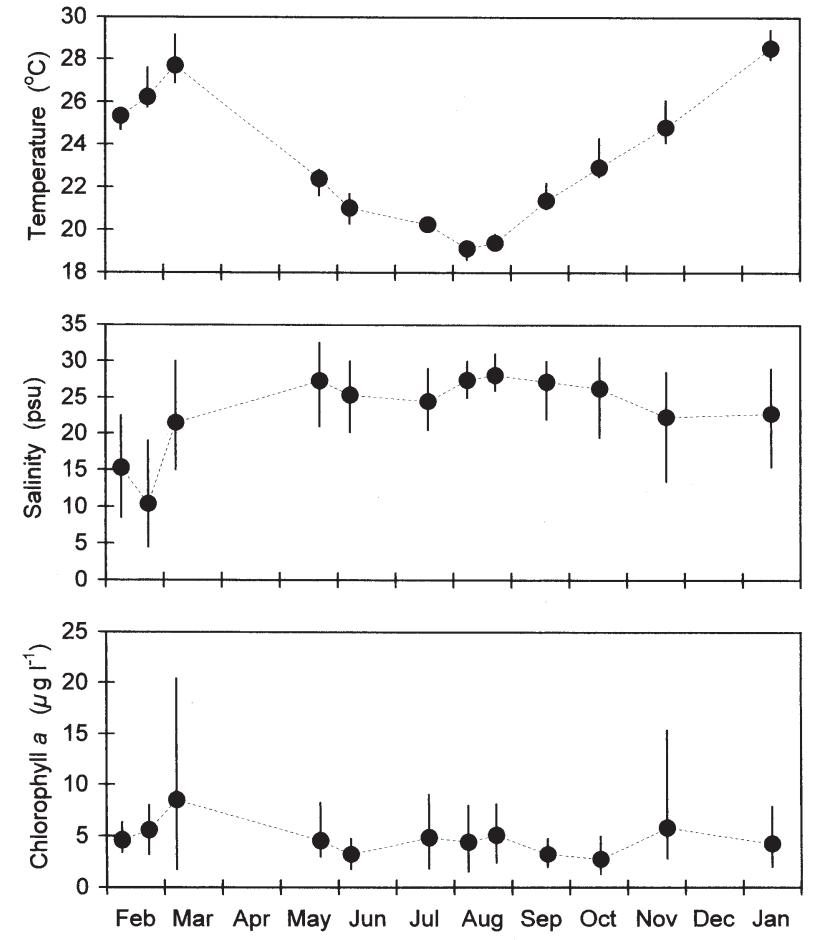

FIG. 2. - Seasonal variations in water temperature, salinity and chlorophyll $a$ concentration in the Cananéia Lagoon estuarine system, from February 1995 to January 1996. Closed symbols and vertical bars denote mean values in the water column and their ranges respectively.

\section{RESULTS}

\section{Environmental variables}

Water temperature showed seasonal variation, ranging from $18.6^{\circ} \mathrm{C}$ on 8 August to $29.6^{\circ} \mathrm{C}$ on 15 January (Fig. 2). No thermal stratification was found throughout the year. Salinity varied from 4.5 to 33.0 psu, and was much lower in February (Fig. 2), due to the heavy local rains. Chlorophyll $a$ concentration fluctuated from 1.32 to $20.42 \mu \mathrm{g} \mathrm{l} \mathrm{l}^{-1}$ (Fig. 2). Salinity and chlorophyll $a$ concentration varied dramatically with depth and time. The variations in salinity were associated with the tidal cycle, whereas those in chlorophyll $a$ concentration were inconsistent in pattern.

\section{Abundance}

On each sampling date, the abundance of $T$. turbinata varied considerably with time: coefficients of variation (SD) were 36.4-264.6\% (mean 86.5\%) of daily mean abundance. On most sampling dates, there was no consistent trend of diel variation in abundance: peak abundance was randomly observed 


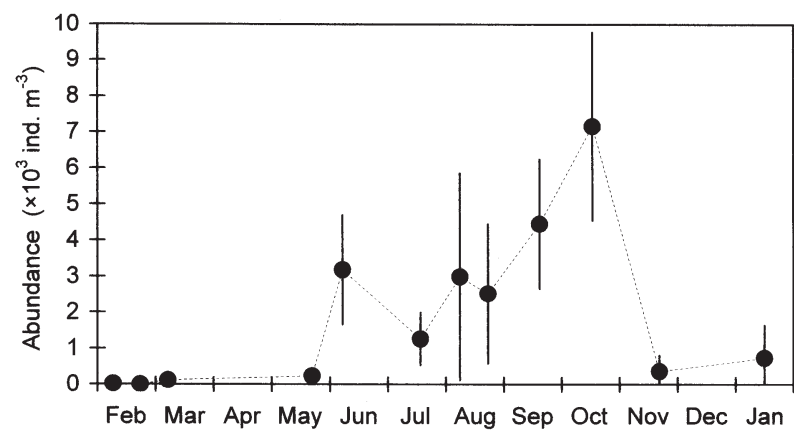

FIG. 3. - Monthly variation in abundance of Temora turbinata (C16) in the Cananéia Lagoon estuarine system, from February 1995 to January 1996. Abundance is expressed as daily mean \pm SD (vertical bars).

with respect to time. There was no statistically significant difference between daytime and nighttime abundances (ANOVA, $p>0.05$ ). The night:day abundance ratio varied from 0.58 in June to 4.62 in November, with an overall mean of 1.11 . On most sampling dates, higher abundances of $T$. turbinata were recorded at times when salinity was higher.

Daily mean abundance of $T$. turbinata varied from $2 \pm 4$ to $7.2 \times 10^{3} \pm 2.6 \times 10^{3}$ ind. $\mathrm{m}^{-3}$ (mean $\pm \mathrm{SD}$ ) (Fig. 3). The population densities were higher in October, but lower from February to May and from November to January.

\section{Population structure}

All of the copepodites (C1-5) and adults (C6) were abundant from June to October, but were rare from February to May and from November to January. These stages showed a similar pattern of temporal variation in abundance, although stages C1-3 were more abundant than the older stages (C4-6), in particular in September and October (Fig. 4). The

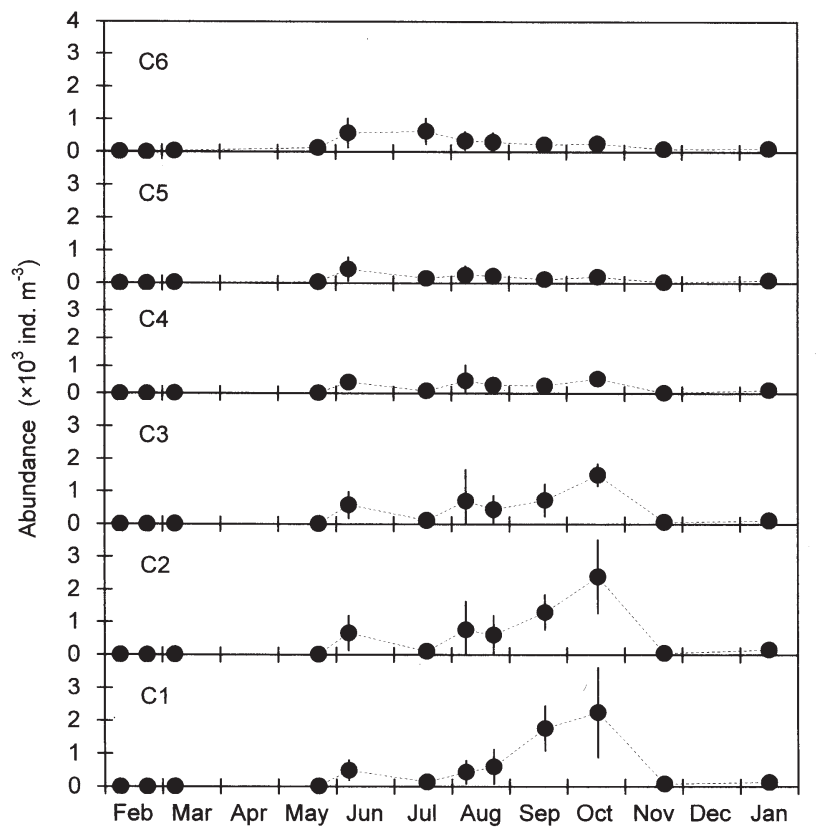

FIG. 4. - Monthly variation in abundance of the stages C1-6 of Temora turbinata in the Cananéia Lagoon estuarine system, from February 1995 to January 1996. Abundance is expressed as daily mean \pm SD (vertical bars).

mean relative abundances of stages $\mathrm{C} 1-6$ were 25.7, 26.5, 18.7, 10.2, 6.9 and $11.9 \%$ respectively.

While the sex composition of C4-6 showed irregular variations, males were slightly more abundant than females: the mean percentage of females in $\mathrm{C} 4$, C5 and C6 were $43.2,40.8$ and $43.1 \%$ respectively.

\section{Effects of the environmental factors}

Temora turbinata was present in the plankton over wide ranges of the environmental variables, but its higher densities were frequently found at temper-

TABLE 1. - Coefficients of Spearman rank correlation between abundance of Temora turbinata and the environmental variables (tidal height and mean temperature, salinity and chlorophyll $a$ concentration in the water column) in the Cananéia Lagoon estuarine system, from February 1995 to January 1996. T: temperature $\left({ }^{\circ} \mathrm{C}\right) ; S$ : salinity (psu); Chl: chlorophyll $a$ concentration $\left(\mu \mathrm{g} 1^{-1}\right)$; TH: tidal height $(\mathrm{m})$; C: copepodite stage; F: female; M: male. Significant correlation: * $0.01<p<0.05 ; * * 0.001<p<0.01 ; * * * p<0.001$.

\begin{tabular}{llcc}
\hline Stage/sex & $T$ & $S$ & Chl \\
\hline Total & $-0.590 * * *$ & $0.744 * * *$ & $-0.617 * * *$ \\
C1 & $-0.563 * * *$ & $0.716 * * *$ & $-0.570 * * *$ \\
C2 & $-0.536 * * *$ & $0.723 * * *$ & $-0.621 * * *$ \\
C3 & $-0.552 * * *$ & $0.712 * * *$ & $-0.581 * * *$ \\
C4 Females & $-0.574 * * *$ & $0.700 * * *$ & $-0.509 * * *$ \\
C4 Males & $-0.566 * * *$ & $0.722 * * *$ & $-0.571 * * *$ \\
C5 Females & $-0.537 * * *$ & $0.640 * * *$ & $-0.447 * * *$ \\
C5 Males & $-0.623 * * *$ & $0.674 * * *$ & $-0.462 * * *$ \\
C6 Females & $-0.533 * * *$ & $0.503 * * *$ & $-0.440 * * *$ \\
C6 Males & $-0.632 * * *$ & $0.549 * * *$ & $-0.458 * *$ \\
F / F+M (C4) & 0.0351 & -0.0906 & 0.145 \\
F / F+M (C5) & $0.352 * *$ & -0.222 & 0.112 \\
F / F+M (C6) & $0.351 * *$ & -0.233 & 0.142 \\
& & & 0.0422 \\
\hline
\end{tabular}




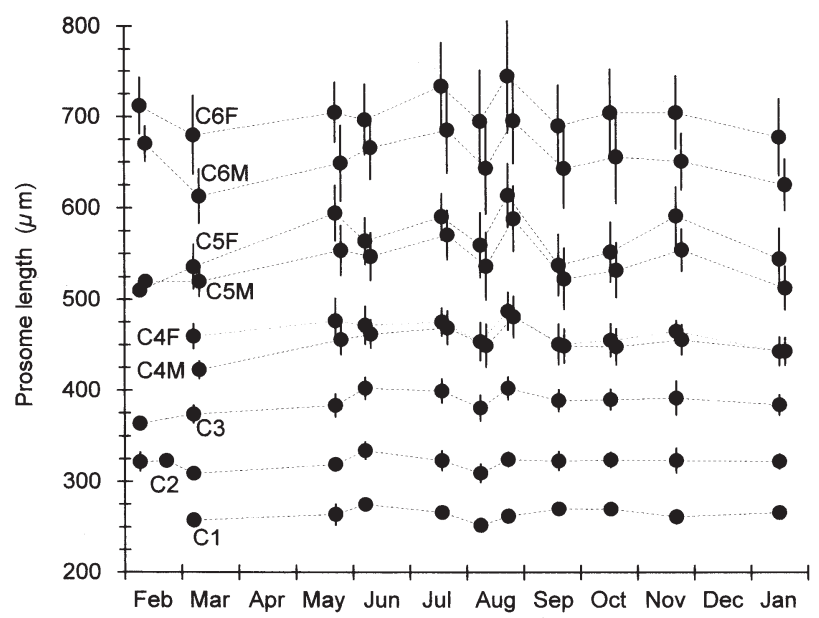

FIG. 5. - Monthly variation in prosome length of the stages C1-6 of Temora turbinata in the Cananéia Lagoon estuarine system, from February 1995 to January 1996. Prosome length is expressed as mean \pm SD (vertical bars). F: female; M: male.

atures lower than ca. $24^{\circ} \mathrm{C}$, salinities higher than ca. 20 psu and chlorophyll $a$ concentrations lower than ca. $8 \mu \mathrm{g} \mathrm{l}^{-1}$. However, it did not show preferential ranges related to tidal height.

Coefficients of correlation between the abundances of C1-6 and the environmental variables are presented in Table 1. The abundance of C1-6 showed significantly positive correlations with salinity and negative correlations with temperature and chlorophyll $a$ concentration. Sex composition (females:total) of C5-6 was positively correlated with temperature.

\section{Body length}

Prosome length of stages C1-6 showed seasonal fluctuation, in particular in older stages (Fig. 5). Their body lengths were generally larger in winter
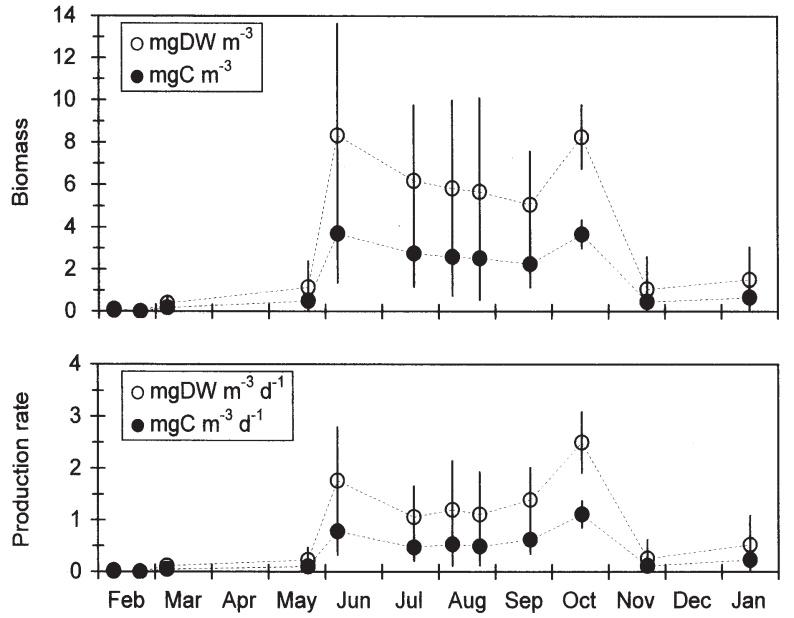

FIG. 6. - Monthly variations in biomass (uppermost) and production rate (lower) of Temora turbinata (C1-6) in the Cananéia Lagoon estuarine system, from February 1995 to January 1996. Biomass and production rate are expressed as daily mean \pm SD (vertical bars).

and smaller in summer. The correlation between prosome length and the environmental variables (temperature, salinity and chlorophyll $a$ concentration) varied depending on the stage and sex. Among these environmental factors, the main factor to explain the size variation was temperature for C3-6, whereas it was chlorophyll $a$ concentration for C1-2 (Table 2).

\section{Biomass and production rate}

Biomass varied from $0.0012 \pm 0.0031$ to $8.335 \pm$ $5.296 \mathrm{mgDW} \mathrm{m}^{-3}$ (daily mean $\pm \mathrm{SD}$ ), or from $0.0005 \pm$ 0.0014 to $3.715 \pm 2.360 \mathrm{mgC} \mathrm{m}^{-3}$. Biomass was higher from June to October, and was lower from February to May and from November to January (Fig. 6).

The pattern of temporal variations in production rate was similar to that of biomass, and the estimat-

TABLE 2. - Multiple linear regression equations of the relationships between prosome length of the developmental stages C1-6 of Temora turbinata and the environmental variables (temperature, salinity and chlorophyll $a$ concentration) in the Cananéia Lagoon estuarine system, from February 1995 to January 1996. PL: prosome length $(\mu \mathrm{m}) ; T$ : mean temperature $\left({ }^{\circ} \mathrm{C}\right)$ in the water column; $S$ : mean salinity (psu) in the water column; $C h l$ : mean chlorophyll $a$ concentration $\left(\mu \mathrm{g} 1^{-1}\right)$ in the water column; $r$ : coefficient of correlation; $n$ : number of cases. Significant correlation: $* 0.01<p<0.05$; ** $0.001<p<0.01$; *** $p<0.001$.

\begin{tabular}{llc} 
Stage/sex & $\begin{array}{l}\text { Multiple linear regression equation } \\
(P L \text { vs. } T, S \text { and } \text { Chl })\end{array}$ & $r$ \\
\hline C1 & $P L=276.46+0.0349 T-0.0768 S-0.393 C h l$ & 56 \\
C2 & $P L=342.01-0.0061 T-0.176 S-0.438 C h l$ & $0.376^{*}$ \\
C3 & $P L=421.15-0.342 T+0.0195 S-0.215 C h l$ & $0.425 * *$ \\
C4 Female & $P L=447.12-0.264 T+0.234 S+0.208 C h l$ & $0.441^{* *}$ \\
C4 Male & $P L=486.96-0.475 T+0.120 S+0.0860 C h l$ & $0.432^{*}$ \\
C5 Female & $P L=601.86-0.353 T+0.0827 S+0.152 C h l$ & $0.551^{* * *}$ \\
C5 Male & $P L=597.33-0.459 T+0.0893 S+0.148 C h l$ & $0.399 *$ \\
C6 Female & $P L=778.09-0.452 T+0.0131 S+0.190 C h l$ & $0.502^{* * *}$ \\
C6 Male & $P L=822.90-0.631 T-0.182 S-0.0844 C h l$ & $0.446 *$ \\
& & 57 \\
\end{tabular}


ed production rates varied from $0.0002 \pm 0.0006$ to $1.115 \pm 0.261 \mathrm{mgC} \mathrm{m}^{-3} \mathrm{~d}^{-1}$ (daily mean $\pm \mathrm{SD}$ ) (Fig. $6)$. The mean ratio of daily production rate to biomass (daily $P / B$ ratio) varied from 0.17 to $0.45 \mathrm{~d}^{-1}$.

\section{DISCUSSION}

Although Temora turbinata has been found to appear recently in various estuarine waters of Brazil (e.g. Araújo and Montú, 1993; Muxagata and Gloeden, 1995; De La Rocha, 1998), nothing has been known on the diel and seasonal occurrence of this species in these waters. Abundance of T. turbinata varied considerably during the 24 -h periods, not showing a consistent trend of diel variation in abundance in relation to time of day, as similarly observed for marine zooplankton (e.g. copepods) in the Cananéia Lagoon estuarine system (Ara, 1998, 2001a, c) and in other estuarine and neritic environments (Sameoto, 1975; Lee and McAlice, 1979; Gagnon and Lacroix, 1981; Dauvin et al., 1988). On most sampling dates, its higher population densities were recorded at times when salinities were higher. Therefore, in the Cananéia Lagoon estuarine system the position of its population centre might move depending on the tidal condition. During the study period, $T$. turbinata appeared in the plankton over wide ranges of temperature and salinity, but its higher population densities were found from autumn to early spring. A similar seasonal occurrence of $T$. turbinata was observed in previous studies carried out in subtropical waters along the eastern coast of the U.S.A. and Mexico (Woodmansee, 1958; Suárez-Morales and Gasca, 1996). However, T. turbinata was found to be abundant throughout the year in Kingston Harbour, Jamaica, where there is little annual variation in temperature $\left(27-30^{\circ} \mathrm{C}\right)$ and salinity (34-36\%o) (Hopcroft et al., 1998a). Judging from these seasonal occurrences of $T$. turbinata mentioned above, temperature could be less limiting to the occurrence of T. turbinata than salinity.

One of the characteristic aspects of calanoid copepods is their stage composition that is commonly skewed toward younger stages rather than older stages (e.g. adults), as observed for T. turbinata (see Fig. 5). In the present study, when population density of $T$. turbinata decreased, the proportion of C6 increased proportionally $(r=0.475, p<0.01)$, as contrary did the proportion of $\mathrm{C} 1(r=0.500, p<$ $0.01)$. This indicates that older stages might have higher tolerance to environmental stress than their

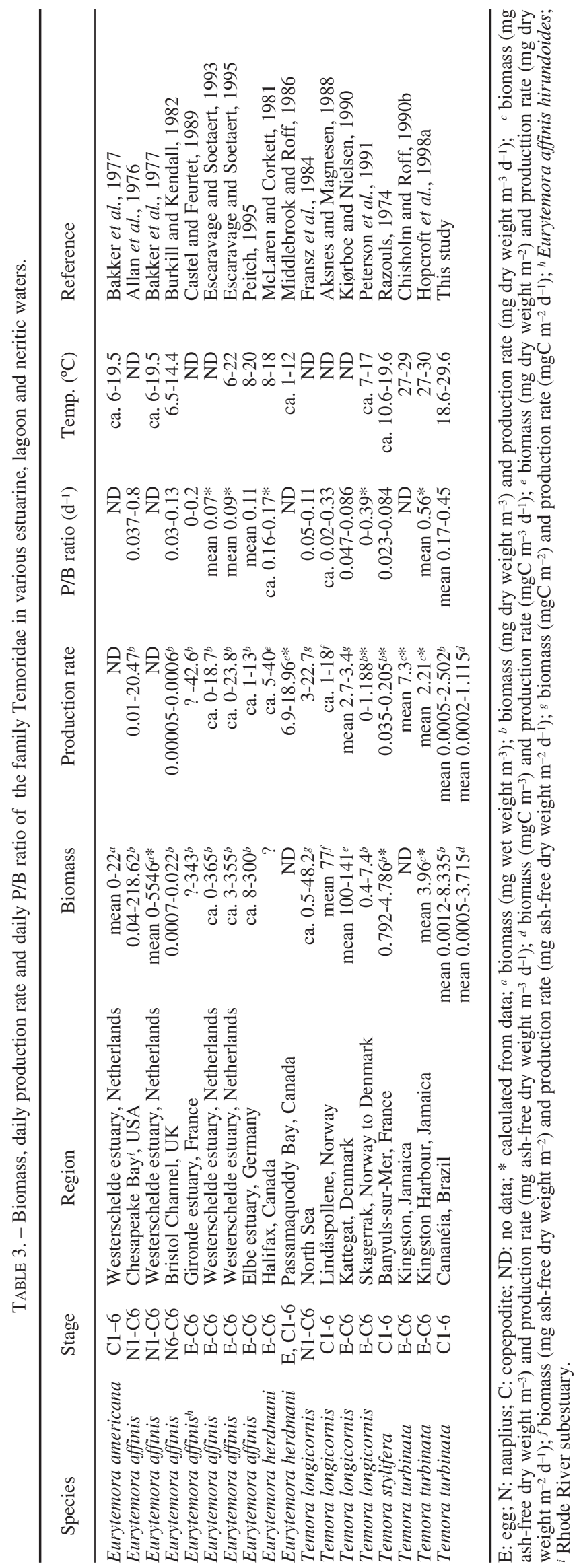


younger stages. During periods of low population density, the dominance of adults is advantageous to recover its population size (Heinle, 1970; Sabatini, 1990; Zaballa and Gaudy, 1996).

Biomass determinations have been done for some Temora and Eurytemora species of the family Temoridae in various estuarine, lagoonal and neritic waters around the world. Although in the present study the biomass of $T$. turbinata was determined only for C1-6, not including the eggs and naupliar stages, the biomasses were higher than those obtained for Temora species, but were much lower than those obtained for Eurytemora species (see Table 3).

The maximum production rates of $T$. turbinata obtained in the present study were higher than those obtained for Temora species, but were lower than those obtained for Eurytemora species (Table 3). However, daily $\mathrm{P} / \mathrm{B}$ ratios obtained for $T$. turbinata in the present study were higher than those obtained for all species of the Temoridae family in other estuarine, lagoonal and neritic waters (Table 3). This can be attributed to higher temperatures in the Cananéia Lagoon estuarine system than in other waters (Table 3 ).

During the study period, $T$. turbinata constituted $6.0,8.3$ and $7.8 \%$ of the annual copepod community abundance, biomass and production rate respectively. This indicates that in the Cananéia Lagoon estuarine system T. turbinata was one of the important copepod species such as Acartia lilljeborgi, A. tonsa, Oithona hebes, O. oswaldocruzi, Pseudodiaptomus acutus, Paracalanus crassirostris and Euterpina acutifrons (Ara, 1998, 2001a, c). The present study showed that the exotic copepod $T$. turbinata, which recently immigrated into the Cananéia Lagoon estuarine system, played an important role as a secondary producer in this environment.

\section{ACKNOWLEDGEMENTS}

I thank Drs Luiz Roberto Tommasi, Luz Amélia Vega-Pérez, Tsui Hua Liang and Simone Ribeiro Heitor for their helpful assistance and valuable comments. This research was financially supported by the Conselho Nacional de Desenvolvimento Científico e Tecnológico (CNPq), the Instituto Oceanográfico da Universidade de São Paulo (IOUSP) and the Fundação de Estudos e Pesquisas Aquáticas (FUNDESPA).

\section{REFERENCES}

Aksnes, D.L. and T. Magnesen. - 1988. A population dynamics approach to the estimation of production of four calanoid copepods in Lindåspollene, western Norway. Mar. Ecol. Prog. Ser., 45: $57-68$

Allan, J.D., T.G. Kinsey and M.C. James. - 1976. Abundance and production of copepods in the Rhode River subestuary of Chesapeake Bay. Chesapeake Sci., 17: 86-92.

Ara, K. - 1998. Variabilidade temporal e produção dos copépodos no complexo estuarino-lagunar de Cananéia, São Paulo, Brasil. Ph.D. Thesis. Universidade de São Paulo.

Ara, K. - 2001a. Temporal variability and production of the planktonic copepods in the Cananéia Lagoon estuarine system, São Paulo, Brazil. II. Acartia lilljeborgi. Plankton Biol. Ecol., 48: 35-45.

Ara, K. - 2001b. Length-weight relationships and chemical content of the planktonic copepods in the Cananéia Lagoon estuarine system, São Paulo, Brazil. Plankton Biol. Ecol., 48: 121-127.

Ara, K. - 2001c. Temporal variability and production of Euterpina acutifrons (Copepoda: Harpacticoida) in the Cananéia Lagoon estuarine system, São Paulo, Brazil. Hydrobiologia, 453: $177-187$.

Araújo, H.M.P. and M. Montú. - 1993. Novo registro de Temora turbinata (Dana, 1849) (Copepoda, Crustacea) para águas atlânticas. Nauplius, 1: 89-90.

Bakker, C., W.J. Phaff, M. van Ewijk-Rosier and N. De Pauw. 1977. Copepod biomass in an estuarine and a stagnant brackish environment of the S. W. Netherlands. Hydrobiologia, 52: 3-13.

Bandaranayake, W.M. and P. Gentien. - 1982. Carotenoids of Temora turbinata, Centropages furcatus, Undinula vulgaris and Euchaeta russelli. Comp. Biochem. Physiol., 72B: 409-414.

Binet, D. - 1977. Cycles biologiques et migrations ontogenétique chez quelques copépodes pélagiques des eaux Ivoiriennes. Cah. O.R.S.T.O.M., Ser. Oceanogr., 15: 111-138.

Bradford-Grieve, J.M., E.L. Markhaseva, C.E.F. Rocha and B. Abiahy. - 1999. Copepoda. In: D. Boltovskoy (ed.), South Atlantic Zooplankton, pp. 869-1098. Backhuys Publishers, Leiden.

Burkill, P.H. and T.F. Kendall. - 1982. Production of the copepod Eurytemora affinis in the Bristol Channel. Mar. Ecol. Prog. Ser., 7: 21-31.

Castel, J. and A. Feurtet. - 1989. Dynamics of the copepod Eurytemora affinis hirundoides in the Gironde estuary: origin and fate of its production. Sci. Mar., 53: 577-584.

Chisholm, L.A. and J.C. Roff. - 1990a. Size-weight relationships and biomass of tropical neritic copepods off Kingston, Jamaica. Mar. Biol., 106: 71-77.

Chisholm, L.A. and J.C. Roff. - 1990b. Abundance, growth rate, and production of tropical neritic copepods off Kingston, Jamaica. Mar. Biol., 106: 79-89.

Cordell, J.R. and S.M. Morrison. - 1996. The invasive Asian copepod Pseusodiaptomus inopinus in Oregon, Washington, and British Colombia estuaries. Estuaries, 19: 629-638.

Dauvin, J.-C., E. Thiébaut and Z. Wang. - 1998. Short-term changes in the mesozooplanktonic community in the Seine ROFI (Region of Freshwater Influence) (eastern English Channel). J. Plankton Res., 20: 1145-1167.

De La Rocha, C.L. - 1998. Variação temporal da comunidade zooplanctônica e produção anual do Copepoda Acartia lilljeborgi na enseada da Praia do Segredo (São Sebastião - S.P.). M.Sci. Dissertation. Universidade de São Paulo.

Escaravage, V. and K. Soetaert. - 1993. Estimating secondary production for the brackish Westerschelde copepod population Eurytemora affinis (Poppe) combining experimental data and field observations. Cah. Biol. mar., 34: 201-214.

Escaravage, V. and K. Soetaert. - 1995. Secondary production of the brackish copepod communities and their contribution to the carbon fluxes in the Westerschelde estuary (The Netherlands). Hydrobiologia, 311: 103-114.

Fleminger, A. - 1975. Geographical distribution and morphological divergence in American coastal zone planktonic copepods of the genus Labidocera. In: L.E. Cronin (ed.), Chemistry, Biology and the Estuarine System, pp. 392-419. Academic Press, New York.

Fleminger, A. and S.H. Kramer. - 1988. Recent introduction of an Asian estuarine copepod, Pseudodiaptomus marinus (Copepoda: Calanoida), into southern California embayments. Mar. Biol., 98: 535-541. 
Fransz, H.G., J.C. Miquel and S.R. Gonzalez. - 1984. Mesozooplankton composition, biomass and vertical distribution, and copepod production in the stratified central North Sea. Neth. J. Sea Res., 18: 82-96.

Gagnon, M. and G. Lacroix. - 1981. Zooplankton sample variability in a tidal estuary: an interpretative model. Limnol. Oceanogr., 26: 401-413.

Haedrich, R.L. and D.C. Judkins. - 1979. Macrozooplankton and its environment. In: S. Van der Spoel and A.C. Pierrot-Bults (eds.), Zoogeography and Diversity in Plankton, pp. 4-28. Edward Arnold, London.

Harari, J. and A.R. Mesquita. - 1995. Tábuas das marés de Ubatuba, Santos e Cananéia para os anos de 1996 e 1997. Relatório Inteiro do IOUSP, 37: 1-28.

Heinle, D.R. - 1970. Population dynamics of exploited cultures of calanoid copepods. Helgoländer wiss Meeresunters., 20: 360-372.

Hirota, R. - 1981. Dry weight and chemical composition of the important zooplankton in the Setonaikai (Inland Sea of Japan). Bull. Plankton Soc. Japan, 28: 19-24.

Hirst, A. and M. Sheader. - 1997. Are in situ weight-specific growth rates body-size independent in marine planktonic copepods? A re-analysis of the global syntheses and a new empirical model. Mar. Ecol. Prog. Ser., 154: 155-165.

Hopcroft, R.R. and J.C. Roff. - 1998a. Zooplankton growth rates: the influence of female size and resources on egg production of tropical marine copepodites. Mar. Biol., 132: 79-86.

Hopcroft, R.R. and J.C. Roff. - 1998b. Zooplankton growth rates: the influence of size in nauplii of tropical marine copepodites. Mar. Biol., 132: 87-96.

Hopcroft, R.R., J.C. Roff and D. Lombard. - 1998a. Production of tropical copepods in Kingston Harbour, Jamaica: the importance of small species. Mar. Biol., 130: 593-604.

Hopcroft, R.R., J.C. Roff, M.K. Webber and J.D.S. Witt. - 1998b. Zooplankton growth rates: the influence of size and resources in tropical marine copepodites. Mar. Biol., 132: 67-77.

Kiørboe, T. and T.G. Nielsen. - 1990. Effects of wind stress on vertical water column structure, phytoplankton growth, and productivity of planktonic copepods. In: M. Barnes and R.N. Gibson (eds.), Trophic Relationships in the Marine Environment, pp. 28-40. Aberdeen University Press, Aberdeen.

Lee, W.Y. and B.J. McAlice. - 1979. Sampling variability of marine zooplankton in a tidal estuary. Estuar. coast. mar. Sci., 8: $565-582$.

López-Salgado, I. and E. Suárez-Morales. - 1998. Copepod assemblages in surface waters of the western Gulf of Mexico. Crustaceana, 71: 312-330.

Lorenzen, C.J. - 1967. Determination of chlorophyll and pheo-pigments: spectrophotometric equations. Limnol. Oceanogr., 12: 343-346.

Matsumura-Tundisi, T. - 1972. Aspectos ecológicos do zooplâncton da região lagunar de Cananéia com especial referência aos Copepoda (Crustacea). Ph.D. Thesis. Universidade de São Paulo.

McLaren, I.A. and C.J. Corkett. - 1981. Temperature-dependent growth and production by a marine copepod. Can. J. Fish. aquat. Sci., 38: 77-83.

Mesquita, A.R. and J. Harari. - 1993. Tábuas das marés de Ubatuba e de Cananéia para os anos de 1994 e 1995. Relatório Inteiro do IOUSP, 35: 1-20.
Middlebrook, K. and J.C. Roff. - 1986. Comparison of methods for estimating annual productivity of the copepods Acartia hudsonica and Eurytemora herdmani in Passamaquoddy Bay, New Brunswick. Can. J. Fish. aquat. Sci., 43: 656-664.

Muxagata, E. and I.M. Gloeden. - 1995. Ocorrência de Temora turbinata Dana, 1849 (Crustacea: Copepoda) no estuário da Lagoa dos Patos, RS, Brasil. Nauplius, 3: 163-164.

Orsi, J.J., T.E. Bowman, D.C. Marelli and A. Hutchinson. - 1983. Recent introduction of the planktonic calanoid copepod Sinocalanus doerri (Centrogagidae) from mainland China to the Sacramento-San Joaquim Estuary of California. J. Plankton Res., 5: 357-375.

Peitsch, A. - 1995. Production rates of Eurytemora affinis in the Elbe estuary, comparison of field and enclosure production estimates. Hydrobiologia, 311: 127-137.

Peterson, W.T., P. Tiselius and T. Kiørboe. - 1991. Copepod egg production, moulting and growth rates, and secondary production, in the Skagerrak in August 1988. J. Plankton Res., 13: 131-154.

Razouls, C. - 1974. Variations annuelles quantitatives de deux espèces dominantes de copépodes planctoniques Centropages typicus et Temora stylifera de la région de Banyuls: cycles biologiques et estimations de la production. III. - Dynamique des populations et calcul de leur production. Cah. Biol. mar., 15: $51-88$.

Roff, J.C., J.T. Turner, M.K. Webber and R.R. Hopcroft. - 1995. Bacterivory by tropical copepod nauplii: extent and possible significance. Aquat. Microbial Ecol., 9: 165-175.

Sabatini, M.E. - 1990. Ciclo annual del copépodo Acartia tonsa Dana 1849 en la zona interna de la Bahía Blanca (Provincia de Buenos Aires, Argentina). Sci. Mar., 53: 847-856.

Sameoto, D.D. - 1975. Tidal and diurnal effects on zooplankton sample variability in a nearshore marine environment. J. Fish. Res. Bd Can., 32: 347-366.

Sokal, R.R. and F.J. Rohlf. - 1981. Biometry. W.H. Freeman \& Co., San Francisco, 859 pp.

Suárez-Morales, E. and R. Gasca. - 1996. Planktonic copepods of Bahía de la Ascensión, Caribbean coast of Mexico: a seasonal survey. Crustaceana, 69: 162-174

Suárez-Morales, E. and R. Gasca. - 1997. Copépodos (Crustacea) de aguas superficiales del Mar Caribe Mexicano (mayo, 1991). Rev. Biol. Trop., 45: 1523-1529.

Suárez-Morales, E. and R. Gasca. - 2000. The planktonic copepod community at Mahahual reef, western Caribbean. Bull. mar. Sci., 66: 225-267.

Uye, S. - 1982. Length-weight relationships of important zooplankton from the Inland Sea of Japan. J. oceanogr. Soc. Japan, 38: $149-158$.

Woomansee, R.A. - 1958. The seasonal distribution of the zooplankton off Chicken Key in Biscayne Bay, Florida. Ecology, 39: $247-262$.

Zaballa, J.D. and R. Gaudy. - 1996. Seasonal variations in the zooplankton and in the population structure of Acartia tonsa in a very eutrophic area: La Habana Bay (Cuba). J. Plankton Res. 18: $1123-1135$.

Scient. ed.: R. Anadón 